Darwin's rejection of Christianity (p.9):

Darwin reserved this uncompromising expression of his religious views for the private autobiography that he wrote for his family. Had he not done so it is inconceivable that T.H. Huxley could have abandoned his war against hypocrisy and helped to carry Darwin's coffin into Westminster Abbey in 1882 .

It is inconceivable that Huxley did not know Darwin's views on religion Darwin was not reticent about them to correspondents - and that he should not have applauded them. Where was the hypocrisy?

Howard's book is essentially a careful exposition and critique of Darwin's arguments in the Origin (and in the Descent of Man for the evolution of man). It is in the structure of the arguments that he is principally interested. Of course he does not neglect the factual evidence, but produces usually only the minimum of it for example his comments on the cogency of geological, geographical, taxonomic and embryological information in establishing that evolution had occurred (pp.37-49). Similarly, in summarizing the modern position on natural selection he merely remarks (p.87),

Natural selection and the evolution of natural populations have been observed directly, even in man. There is now no doubt that natural selection is a mechanism of evolutionary change. Whether it is the exclusive mechanism of evolutionary change is still occasionally debated.

And he accepts Darwin's own belief that he had spent too much time on barnacles (p.5) without analysing what he had got from them.

Howard's exposition of ideas and their inter-relatedness is much more full, and he seems especially interested in predictability and unpredictability and their role in the evolutionary debate. He remarks (p.24):

If mutual competition between organisms was a more important selective influence than mere climatic or geographic change, then the direction of evolution of a species or of an interacting group of species, became effectively impossible to determine.

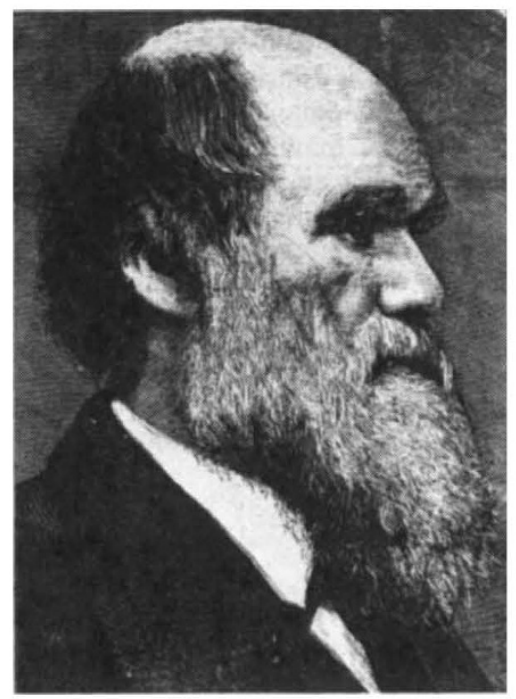

And, after a supporting quotation from the Origin,

It is important to recognise this instance for what it is, namely a hypothetical scenario for fluctuations in frequency of different kinds of organisms that are all subtly related to each other, initiated by introducing into a dynamic equilibrium a single small change. . .

Here is the physiologist pre-adapted for seizing the complexities of a dynamic system and comprehending the modes (and pitfalls) of its analysis - a valuable approach.
Wilma George's book, written in a particularly attractive and lively style, inevitably covers much of the same ground but is effectively complementary to Howard's in its mode of treatment. She has travelled extensively, realizing the facts of natural history, adaptation and biogeography at first hand - an equally valuable approach. She uses all of Darwin's works very effectively, showing how his interests grew on a wide front, and provides the best short account that I know of just why he was so interested in barnacles, what he got from them and how the ideas acquired led on to later interests (polymorphism, sexuality, insectivorous plants and the fertilization of orchids, for example). Her insight into the development of his ideas on coral reefs in relation to other geological ideas is particularly clearly expressed, and she relates Darwin most effectively to other workers before, at the time, and after. She gives a more concrete exposition of subsequent work in population genetics, natural selection and speciation, than does Howard.

Either book can be read with pleasure by itself; the two combined make a first-class introduction to the subject. Both authors make suggestions for further reading, to which should be added Dorothy Nelkin's spine-chiller Science Textbook Controversies and the Politics of Equal Time, published by MIT Press in 1977. Both glance at the present situation in evolutionary thought, and both expatiate on the forces of unreason, but neither, it seems to me, appreciates just how powerful and dangerous they are. Nelkin's book is a necessary addition.

A.J. Cain is Derby Professor of Zoology at the University of Liverpool.

Miocene-early Pliocene gap in the story.

In bringing us, with Sir Alister's blessing, an extended statement of the case for his ideas, Mrs Morgan adds arguments of her own. She sees in face-to-face copulation an important behaviour pattern shared by mankind and many aquatic mammals, but not seen in infra-human primates. Emotional weeping is another such behaviour. She also believes that speech as a mode of communication may have evolved as the limitations of smell and sight in an aquatic environment made themselves felt. In this, and in the suggestion that underwater childbirth may once have been the norm, she seems to envisage a more completely aquatic phase than Hardy originally did.

The additional arguments do not, I think, greatly strengthen the case. Mrs Morgan herself sees face-to-face copulation in mankind as a consequence of bipedalism and hence, at most, as a secondary consequence of an aquatic phase. On the shedding of tears the position is not simple. While seals and sea 
otters apparently weep for emotional reasons as do we, so too do Indian elephants. Elephants like whales have, however, reduced their lachrymal gland and increased the Harderian gland contribution to tears. Mrs Morgan is willing to accept elephants as fellow travellers to the water and back, on this and other grounds, but until we are more confident about the functions of copious tear production it seems best to be cautious.

However the fossil record will doubtless have the final say, and it is becoming yearly more complete. Mrs Morgan re-publishes the suggestion of another supporter of the Hardy hypothesis, L.P. La Lumiere. He believes that the aquatic phase was experienced during early Pliocene times on the coast of the Red Sea. At a time of presumed deforestation, changes in land and water levels providentially provided an island refuge. La Lumiere offers precise predictions of where the missing links will be found.

This book is written for a lay public and is too brief, and too superficial, to satisfy a serious critic. The bibliography, for example, fails to include many of the authorities referred to in the text. The book is also marred by occasional carelessness I had to read one passage several times to extract from it a meaning other than that women and sirenians were alone in having two pectoral mammary glands. But the writing is lively and enthusiastic and it will surely engage the interest of those for whom it was written.

D.R. Newth was formerly Regius Professor of Zoology in the University of Glasgow.

\section{A cycle ride to Stockholm}

\section{M.F. Perutz}

Reminiscences and Reflections. By Hans Krebs in collaboration with Anne Martin. Pp.250. ISBN 0-19-854702-1. (Oxford University Press: 1982 .) $£ 12.50, \$ 19.95$

ON 14 December 1932 the dean of the medical faculty of the University of Freiburg, Professor E. Rehn, reported to the Ministry of Education,

As an assistant physician Dr Krebs has shown not only outstanding scientific ability, but also unusual human qualities. His . . . paper on the synthesis of urea in the animal body . . . will be regarded as one of the classics of medical research .

Four months later, shortly after Hitler seized power, this same dean sent him a "Notification of Immediate Removal from Office", obediently implementing the Minister's orders against members of the Jewish race.

Krebs kept several such letters and also various press cuttings from those days and had them reproduced as facsimiles in his book. There is the "Manifesto Against the UN-German Spirit" published by the Freiburg Student Union and posted in the University: "Our most dangerous adversary is the Jew and he who serves him. The Jew can think only as a Jew. If he writes German he lies. The German who writes German, but thinks un-German is a traitor . . "'. The Rector of the University, von Möllendorf, ordered the posters to be removed, whereupon the Minister replaced him by the existentialist philosopher Martin Heidegger who endorsed them and proclaimed, "German students! . . . Your existence must not be ruled by learned axioms and ideas .... Only the Führer himself constitutes today's and tomorrow's reality and law. Daily and hourly must you fortify your faithful obedience ...". Most of Krebs's colleagues acquiesced, but one Dr Arthur Jores dared send his and Krebs's former Jewish chief, by then in New York, a reprint with a personal dedication. The envelope was opened by a Nazi colleague who denounced him. Jores was dismissed from his post, publicly branded as an enemy of his country and, in due course, imprisoned.

Despite these harrowing experiences and the extermination of 20 of his relatives Krebs does not follow the example of Einstein who refused ever to set foot in Germany again, but declares in the book that "to be anti-German seems to me just as bad as being anti-semitic". After the War he therefore persuaded the Biochemical Society to re-establish contact with Germany by inviting several known anti-Nazis to the First International Congress of Biochemistry at Cambridge.

Krebs's discovery of the ornithine cycle of urea synthesis had caught the eye of $\mathrm{F}$. Gowland Hopkins, then Professor of Biochemistry at Cambridge and President of the Royal Society. When he heard of Krebs's dismissal, he immediately invited him to Cambridge. The Rockefeller Foundation which had already supported Krebs's research at Freiburg, provided the money, and continued to support his research for the next 30 years. Krebs was deeply touched by the warmth of his reception at the Biochemistry Department at Cambridge and by the generous hospitality and friendliness of English people generally. His book is permeated by affection for England, which he epitomizes by Carl Zuckmayer's, another refugee's, saying that "home is not where a man is born but where he wants to die"'.

How Prussian Krebs remained all the same! He writes,
.. I expected a lot from my associates - hard disciplined work and the ability to accept my criticisms . . . . I have tried to be fair, honest and helpful, and not to demand more of others than I do of myself ..... We criticised each other ruthlessly - we knew it was done honestly, in good faith and in a spirit of helpfulness.

Few Englishmen would write such solemn stuff about themselves. I cannot imagine Francis Crick declaring in his memoirs that he demolished my cherished 1949 model of haemoglobin, "honestly, in good faith and in a spirit of helpfulness", rather than admitting to a certain mischievous satisfaction at the dastardly deed.

For people who complain that money for research has become hard to come by, Krebs's early career makes salutary reading. His father, a doctor in Hildesheim, had to support him throughout his medical studies. After graduating Krebs wanted to do research, but paid research posts were rare, never advertised and obtainable only by what used to be known in my native Vienna as Protektion, which signified a mix of sycophancy, nepotism and the old boy network. Eventually Krebs found an unpaid post at the Third Medical Clinic in Berlin where another biochemist who later made his name, Bruno Mendel, became one of his colleagues. One night the Mendels were invited to the Einsteins when Otto Warburg was among the guests. When Warburg told Mendel that he was looking for a collaborator, Mendel recommended Krebs and also raised the money privately to pay him a modest salary. Krebs regards his four years with Warburg as formative for his career and expresses the greatest admiration for Warburg's scientific genius, regardless of his despotic, egotistical and sometimes malicious behaviour, his lack of confidence in Krebs's own talent and his refusal to help him find a university post where Krebs would have to attach himself "to some old ass of a professor". Only in medicine would Krebs be able to make a living, Warburg told him. Warburg demanded of his staff that they work punctually from eight to six, six days a week, a precept which Krebs himself seems to have followed for much of his life. At 11 o'clock on the Monday morning after reading of Warburg's Draconian regime, I walked into my own biochemistry laboratory to find that only one of my three collaborators had arrived yet. "The other two were still working when I left at midnight", the first reported. This convinced me again that the free coming and going of Cambridge is more conducive to dedicated research than the iron discipline of old Berlin.

Krebs made his first great discovery, the ornithine cycle of urea synthesis, in 1931 and 1932. He used the tissue slice and manometric techniques which Warburg had taught him; another decisive factor was his own invention of the Krebs-Ringer 